\title{
Spatial ecology of adult muskellunge (Esox masquinongy) in the urban Ottawa reach of the historic Rideau Canal, Canada
}

\author{
Nathan C. Gillis ${ }^{1,2}$, Tobias Rapp ${ }^{3}$, Caleb T. Hasler ${ }^{2, a}$, Hedrik Wachelka ${ }^{4}$ and Steven J. Cooke ${ }^{2,5}$ \\ 1 Carleton University, Institute of Integrated Science, Ottawa ON, K1S 5B6, Canada \\ 2 Carleton University, Fish Ecology and Conservation Physiology Laboratory, Department of Biology, Ottawa, ON K1S 5B6, Canada \\ 3 Humboldt-University of Berlin, Inland Fisheries Management Laboratory, Faculty of Agriculture and Horticulture, Humboldt-University \\ of Berlin, 10115 Berlin, Germany \\ 4 Muskies Canada Inc., Ottawa Chapter, Ottawa, ON, K1S 5B6, Canada \\ 5 Institute of Environmental Science, Carleton University, Ottawa, ON, K1S 5B6, Canada
}

Received 11 November 2009; Accepted 8 June 2010

\begin{abstract}
The Rideau Canal in Canada was constructed in the 1800s to enable strategic military and commercial transport in eastern Ontario between Lake Ontario and the Ottawa River. Today, the Rideau Canal is managed by Parks Canada and remains an engineered ecosystem, particularly in the urban Ottawa reach $(7 \mathrm{~km}$ long) where it is largely channelized and is partially drained during the winter to protect canal infrastructure (i.e., locks) and provide recreational opportunities (i.e., skating). Interestingly, the Ottawa reach of the Rideau Canal supports one of the few wild urban muskellunge (Esox masquinongy) fisheries in North America supported by natural reproduction. However, little is known about the spatial ecology, residency patterns or survival of this apex freshwater predator in urban environments or canal systems. Radio-telemetry was used to study adult $(N=10$; total size range of 64 to $122 \mathrm{~cm})$ muskellunge in the Ottawa reach of the Rideau Canal over a multiple year period. The seasonal movements and home range of muskellunge were greatest during spring corresponding with the period when water levels in the canal were raised and muskellunge were presumably seeking out suitable spawning habitats following ice-off. During the summer fish ranged throughout the entire $7 \mathrm{~km}$ urban reach of the canal and by early fall muskellunge moved to the deeper parts of the reach and became largely restricted to an embayment known as Dow's Lake prior to the lowering of the canal where they stayed for the entire winter. The same pattern of seasonal movements persisted across several years. None of the tagged muskellunge were stranded from the fall canal drainage. One fish emigrated from the urban reach of the canal during the study period, moving upstream through a lock to an exurban reach. In addition, a single tagged fish died from a winterkill event. Environmental influences such as seasonality and water depth (associated with canal operations) are believed to be the primary mechanisms contributing to habitat selection and movement patterns of muskellunge in this reach of the Rideau Canal. Data on the spatial ecology of muskellunge in the urban reaches of the Rideau Canal will inform management of this unique population of fish to ensure that the historic and ecological values are balanced to preserve this iconic Canadian natural heritage site and its biota.
\end{abstract}

Key words: Radio-telemetry / Home Range / Seasonal Behaviour / Esocidae

\section{Introduction}

The historic Rideau Canal system was built between 1826 and 1832 in eastern Ontario, Canada. The canal spans $202 \mathrm{~km}$ and has 47 working locks and 52 dams, providing a direct route between the Ottawa River (at Ottawa) and Lake Ontario (at Kingston). Although initially constructed to facilitate commercial shipping and national defense (Bumsted 2003), after 1849 the role of the Rideau Canal has changed and is now regarded as a historic National Historic Site of Canada, a Canadian

\footnotetext{
a Corresponding author: chasler@connect. carleton.ca
}

Heritage River, and a UNESCO World Heritage Site (Parks Canada 2005). In the winter months, the water levels in many reaches of the canal are lowered to ensure that canal infrastructure is not damaged by ice and to minimize risk of spring flooding. Although the middle reaches of the canal wind through agricultural and natural areas, the northern end of the canal cuts through the City of Ottawa; Canada's 4th largest urban centre. The Ottawa reach of the canal is $7 \mathrm{~km}$ in length and includes the area between Hartwell's Locks and the Ottawa Lock Station. Although the reach is largely channelized with stone and cement walls and fairly uniform depth (approx. $2 \mathrm{~m}$ depth 
at summer water levels), there is one large embayment known as Dow's Lake which includes several deeper areas (approx. $6 \mathrm{~m}$ depth at summer water levels). The ecology of the system is poorly understood. There have been several studies on the structure of the aquatic community including fish, invertebrates, and macrophytes (e.g., Coad 2001; Phelps et al. 1999; Walker et al., pers. comm.), however, little is known about the spatial ecology of individual fish within the canal (e.g., movement between reaches), seasonal responses to water level management, or mortality associated with partial canal draining prior to winter.

Interestingly, this urban canal reach in Ottawa is home to one of the few wild urban muskellunge (Esox masquinongy) populations in North America that is self-sustained without supplemental stocking. Muskellunge are an iconic trophy sportfish sought after by specialized anglers and are classified as apex predators (Ontario data; Casselman et al. 1999). The species is common to freshwater lakes and rivers of North America and Canada, but is found in less than $0.1 \%$ of Ontario water bodies (Casselman et al. 1999; Scott and Crossman 1973). Habitat selection and movement patterns are likely important for size, as the growth and length of these fish are related to the productivity of their environment, the abundance and size of available prey, and can be influenced by the size of the water body inhabited (Casselman 2007; Dombeck 1979; Murry and Farrell 2007). In addition, as muskellunge inhabit temperate water bodies, seasons likely impact habitat selection and general movement patterns; a phenomenon previously found in northern pike (Esox lucius), a congeneric species (Knight et al. 2008; Kobler et al. 2008a,b). Seasonal habitat preference and movement patterns are directly influenced by the available habitat and the type of water body (Casselman 2007; Miller and Menzel 1986a; Wagner and Wahl 2007). Muskellunge typically increase activity once ice-out occurs and is highest during the spring and fall transitional periods when fish are moving to and from spawning and wintering habitats (Dombeck 1979; Younk et al. 1996). Crossman (1956) found muskellunge during the summer to have low activity. A proportion of a population may move between connected lakes, as was found by Weeks and Hansen (2009), however, muskellunge have demonstrated strong spawning habitat site fidelity (Crossman 1956). In the urban reach of the Rideau Canal, the canal infrastructure restricts upstream and downstream movements during the operational period of the locks. From mid-October to late May, the water in the urban portion of the Rideau Canal is partially drained to the winter levels, and fish must respond to the resulting environmental disturbance. Within the canal system during this time period, Dow's Lake remains at a sufficient water depth, creating a small, yet suitable environment for large fish, though winterkill has been known to occur (Cooke unpublished data).

Although Parks Canada strives to preserve the cultural and natural values of the Canal by allowing for sustainable development on lands bordering the Canal and recreational use of the Canal itself, the agency and its partners (including the Rideau Valley Conservation Authority and the Ontario Ministry of Natural Resources) are somewhat hindered based on the general lack of information on the ecology of the canal ecosystem (Wachelka et al. 2000). In this particular study, adult muskellunge were radio-tagged and tracked over a three-year period to determine seasonal habitat use, movement patterns, and distribution in the urban portion of the Rideau Canal. Data on the spatial ecology of muskellunge in the urban reaches of the Rideau Canal will inform management of this unique population of fish to ensure that the historic and ecological values are balanced to preserve this iconic Canadian natural heritage site and its biota.

\section{Methods}

\section{Study site}

Muskellunge were tracked from 24 November 2006 through 29 December 2009 in the urban reach of the Rideau Canal (N45 $23^{\prime} 23.81$, W75 $\left.42^{\prime} 05.58\right)$, located in Ottawa, Ontario, Canada (Fig. 1). The urban waterway studied here stretches approximately $7 \mathrm{~km}$, connecting the Rideau River to the Ottawa River. Included within this system is Dow's Lake (N45 $\left.23^{\prime} 46.14, \mathrm{~W}^{\circ} 5^{\circ} 42^{\prime} 05.58\right)$, a large man-made lake that is essentially a lentic section of the Rideau Canal, located near downtown Ottawa. The lake is comprised of five gross habitat types, consisting of gravel, silt/sand, rip-rap/gabion basket, boulder, and wall habitats. The macrophyte assemblages are relatively homogenous distributed, dominated by Myriophyllum spicatum and Vallisneria americana, with fish communities characterized as warm water assemblages, dominated by centrarchids. Further details on the lake structure and community can be found in Walker et al. (pers. comm.). Within this region muskellunge were collected, radio-tagged, and tracked over a three year period.

\section{Radio-tagging}

Between 30 September 2006 and 12 November 2007, muskellunge were captured using trap nets and standard hookand-line angling. Radio transmitters (Holohil Ltd., Carp, ON; model AI2, $15 \mathrm{~mm} \times 43 \mathrm{~mm}, 20 \mathrm{~g}$, repetition rate $3.0 \mathrm{~s}$, life expectancy 3 year) with unique frequencies (149.199$149.769 \mathrm{MHz}$ ) were surgically implanted into 10 muskellunge (size range 64-122 cm TL, mean $94 \pm$ SD $17 \mathrm{~cm}$; Table 1), following methods described in Cooke et al. (2003). Prior to surgery, individual muskellunge were anaesthetized in an induction bath of clove oil $\left(0.4 \mathrm{ml} \mathrm{L}{ }^{-1}\right.$ [40 ppm] emulsified in ethanol; Anderson et al. 1997). Following loss of equilibrium, the total length of the fish was measured to the nearest $\mathrm{cm}$. During surgery, a recirculating maintenance dose of anesthetic (12 ppm clove oil) in canal water was used to irrigate the gills. After the procedure, fish recovered in coolers containing canal water until equilibrium was regained (approximately $25 \mathrm{~min}$ ) and were released into Dow's Lake. All tagged fish were captured in Dow's Lake or immediately upstream or downstream of that location.

\section{Tracking and habitat characteristics}

Attempts to locate fish were conducted on approximately a weekly basis, using a portable receiver (SRX 400, Lotek Wireless Inc., Newmarket, Ontario) and a three element yagi 

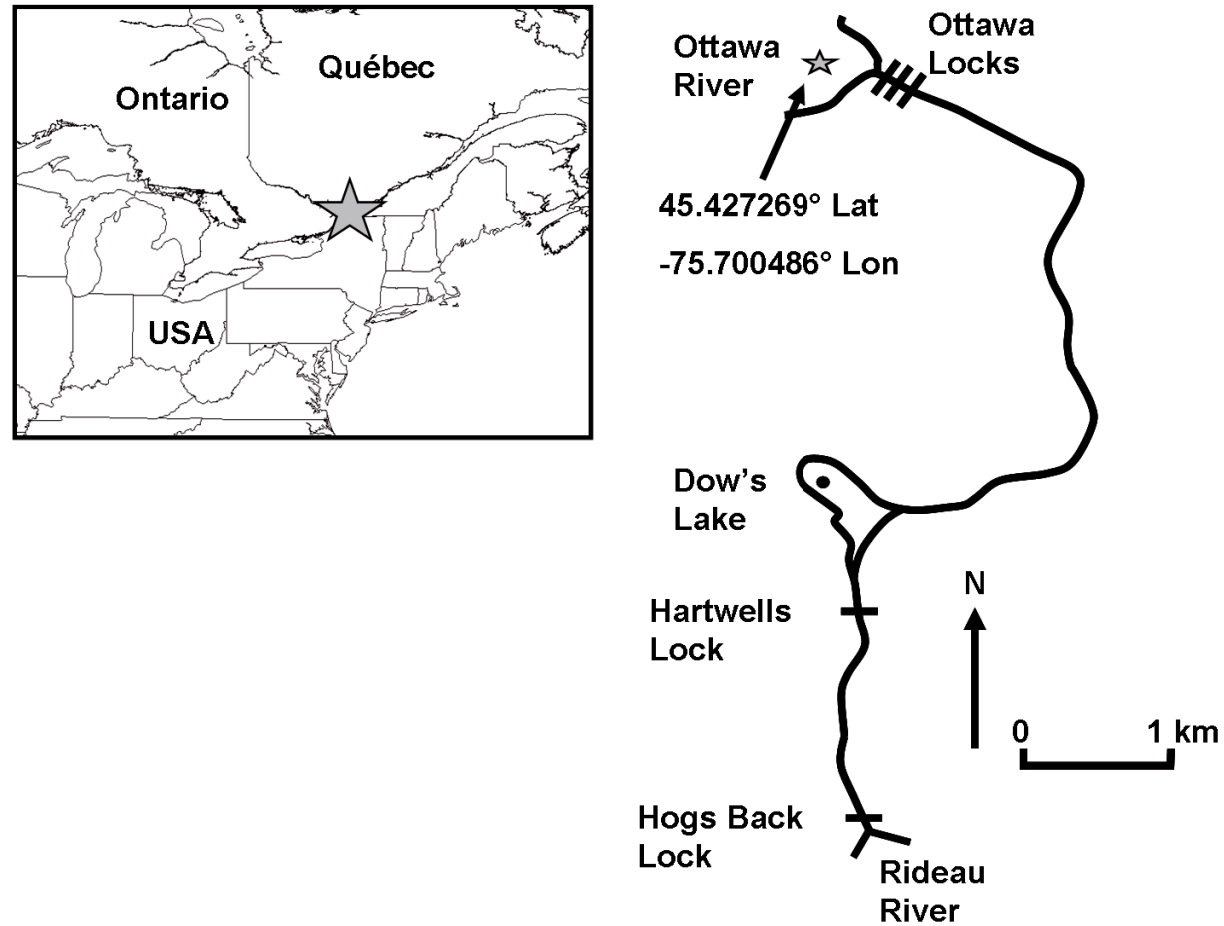

Fig. 1. Map of the urban reach of the Rideau Canal, Ottawa, Canada. The study site contains 5 locks, represented by the Ottawa Lock Station (3), Hartwell's Lock (1), and Hog's Back Lock (1). Inset shows the location of the canal (grey star) in Eastern Canada.

Table 1. Frequencies and total lengths of muskellunge used in this study. The tagging date and number of days each fish was tracked is indicated.

\begin{tabular}{|c|c|c|c|c|c|}
\hline $\begin{array}{c}\text { Fish } \\
\text { Frequency } \\
(\mathrm{MHz})\end{array}$ & Date Tagged & $\begin{array}{c}\text { Total } \\
\text { Length } \\
(\mathrm{cm})\end{array}$ & $\begin{array}{l}\text { Last Date } \\
\text { Tracked }\end{array}$ & $\begin{array}{c}\text { Total Times } \\
\text { Located } \\
\text { (days) }\end{array}$ & Comments \\
\hline 149.611 & Sept. 30, 2006 & 105 & Oct. 06, 2007 & 16 & $\begin{array}{l}\text { Swam through locks at Hog's } \\
\text { Back into Mooney's Bay in early } \\
\text { Oct. } 2007\end{array}$ \\
\hline 149.448 & Nov. 10, 2006 & 74 & Dec. 29, 2008 & 60 & \\
\hline 149.627 & Nov. 24, 2006 & 84 & $\begin{array}{l}\text { April 08, } \\
2007\end{array}$ & 12 & $\begin{array}{l}\text { Found dead in Dow's Lake in mid } \\
\text { April } 2007\end{array}$ \\
\hline 149.487 & Sept. 17, 2007 & 64 & Dec. 29, 2008 & 34 & \\
\hline 149.229 & Sept. 19, 2007 & 109 & Dec. 13,2008 & 46 & \\
\hline 149.199 & Sept. 19, 2007 & 94 & Dec. 29, 2008 & 48 & \\
\hline 149.769 & Sept. 19, 2007 & 122 & Dec. 29, 2008 & 37 & \\
\hline 147.471 & Nov. 12, 2007 & 96 & Dec. 05. 2008 & 41 & \\
\hline 149.739 & Nov. 12, 2007 & 95 & Dec. 29, 2008 & 42 & \\
\hline 149.507 & Nov. 12, 2007 & 96 & Dec. 29,2008 & 43 & \\
\hline
\end{tabular}

antenna. After establishing the general location of the fish, approximate final positions were determined based on the signal strength (Wagner and Wahl 2007). The specific UTM coordinates for transmitter locations were recorded using a geographic positioning system (GPS) receiver, with detailed notes made on fish locations in reference to easily distinguishable landmarks (Curry et al. 2007).

\section{Data analysis}

Muskellunge positions were plotted on a geo-referenced map of the Rideau Canal and analyzed using the animal movement extension (Hooge et al. 1999) for ArcMap (version 9.2, Environmental Systems Research Institute, Redlands, California). The number of localizations per fish can be found in Table 1. Home range and movement patterns between seasons were evaluated using minimal convex polygons (MCP) in combination with kernel distributions (Row and Blouin-Demers 2006). The use of both kernel densities and minimal convex polygons allowed for distinctions to be made between the total length of the canal used and the area of the canal in which seasonal activity was concentrated. Seasons were defined based on the spring and fall equinoxes, and the summer and winter solstices. Total area used by seasons was calculated using MCPs. MCPs represent a non-statistical measure of dispersion over the total area used by an individual, indicating an estimate of home range based on the area of the polygon that encompasses all data points (Rogers and White 2007). Seasonal minimum displacements were then compared 


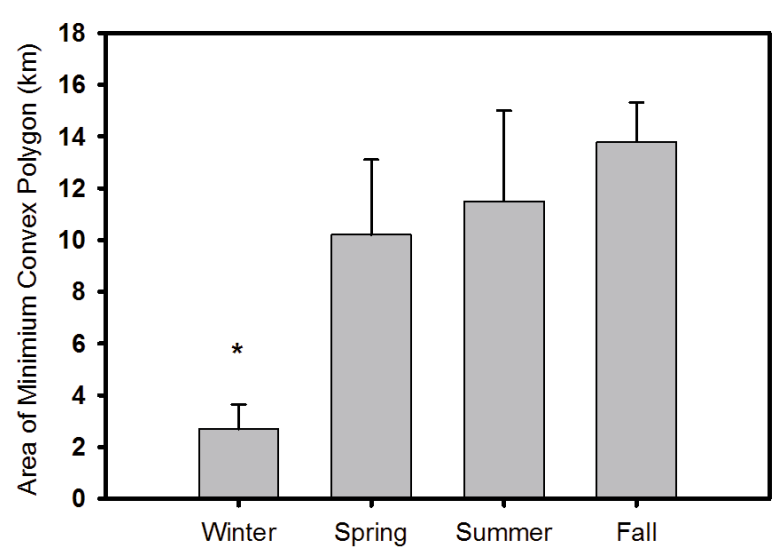

Fig. 2. Home range size measured with minimum convex polygons (Mean $\pm \mathrm{SD}$ ) as recorded by radio telemetry for the representative seasons ( $n=8$; excludes fish that emigrated from the system or died).

using a one-way repeated measure ANOVA, performed using SPSS Statistics 17.0 (SPSS Inc.) and a significance level of $p=0.05$. Kernel density distributions $(95 \%)$ were used to identify and visualize fish "hotspots" in the canal (Rogers and White 2007; Worton 1989). Fish locations were aggregated (i.e., all fish, all locations) by season to determine general habitat preferences for the fish each season.

\section{Results and discussion}

In the course of this three year study, one radio-tagged muskellunge was found dead, likely from a winterkill hypoxia event (fish and tag were found in the early spring immediately following the ice-off date among many dead fish), while another fish moved upstream of the Hog's Back Lock (Fig. 1) and beyond the tracking area. Thus, 8 of the 10 originally radio-tagged fish with total lengths between 64 and $122 \mathrm{~cm}$ were used for analysis of seasonal movement patterns and habitat use in the study site. The home range of muskellunge in the Rideau Canal varied seasonally as evidenced by reductions in the sizes of the MCPs during the winter relative to the summer and fall months (repeated-measures ANOVA; $F_{(1,7)}=46.237, p<0.0001$; Fig. 2). Winter home ranges for all tagged individuals were reduced, suggesting that these fish have limited movement during the colder months of the year. In addition to limited movement, the majority of radiotagged fish inhabited the deepest sections of Dow's Lake close to the shoreline (Fig. 4). Younk et al. (1996) also localized muskellunge in deep water habitats and found that movement was restricted during the winter period. One variable explaining reduced activity in winter is temperature because it affects all biological rates and metabolic processes (Casselman 1978; Magnuson et al. 1979). Similar findings have been observed in northern pike with many metabolic and physiological rates inversely related to temperature, resulting in minimal swimming activity at water temperatures $<6{ }^{\circ} \mathrm{C}$ (Kobler et al. 2008b). Notably, Kobler et al. (2008a) found larger home ranges in female pike during the winter.

Muskellunge minimum displacement increased during the summer months, resulting in expanded home ranges (Fig. 2).

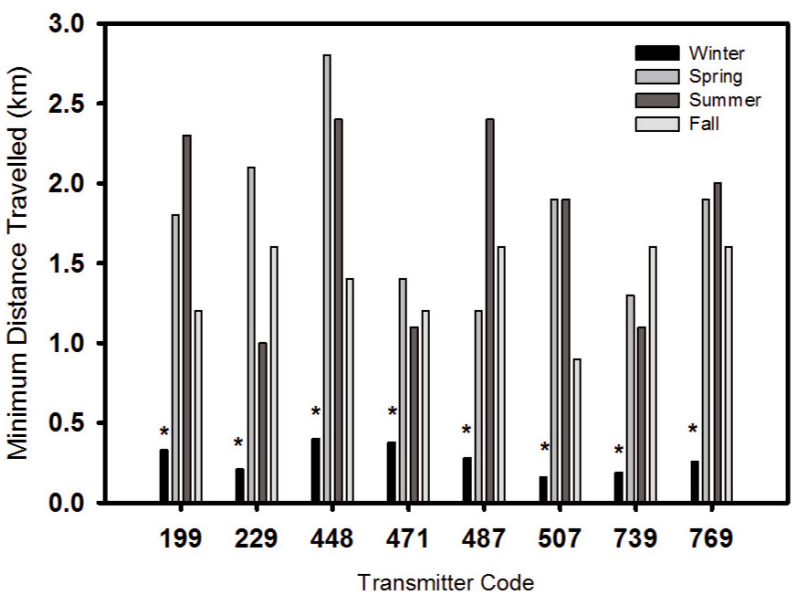

Fig. 3. The minimum displacement for individual muskellunge as recorded by radio telemetry for the representative seasons ( $n=8$; excludes fish that emigrated from the system or died). Minimum displacement is defined as the distance between the upstream and downstream locations of an individual fish within a season.

During this period fish used the majority of the reach between Hartwell's Lock and the Ottawa Lock Station (Fig. 4). Also, fish traveled the greatest distances during the spring and summer (repeated-measures ANOVA; $F_{(1,7)}=228.532$, $p<0.0001$; Fig. 3). The summer movements were greatest during the month of July. The fall movements coincide with transitional periods during which muskellunge travel to overwintering areas. Younk et al. (1996) have described similar seasonal movement patterns of muskellunge in the Mississippi River, with larger mean seasonal movement observed during these transitional periods. Transition to the over-wintering habitat in the fall took place from the end of September to early October, occurring several weeks earlier than previous studies reported, likely due to the fact our study was done at a higher latitude (Younk et al. 1996). Perhaps a stimulus for the movement is the change in water level in early October; however, Kobler et al. (2008a) suggest changes in habitat structure may have influenced larger winter home ranges in female northern pike. The lowering of the water level in the canal likely forces fish to transition to their winter environments, as it is the only habitat remaining at a sufficient water depth. Nonetheless, most of the movements occurred prior to the canal draining indicating that the timing of their movement was most likely related to seasonality rather than canal operations.

Muskellunge spawning takes place during mid to late spring at water temperatures between $9-15{ }^{\circ} \mathrm{C}$, in heavily vegetated shallow-water habitats (Scott and Crossman 1973). Spring warming of the water is often heterogeneous, proceeding most rapidly in shallow waters and shoreline environments (Miller and Menzel 1986b). These regions typically attract muskellunge and likely provide favorable spawning conditions. Movement from the winter ranges to spawning areas occurred in early to mid May, as fish transitioned from the deep water habitats to warm water shoreline environments (Fig. 4). Although there was no direct evidence of spawning in these regions (i.e., no visual confirmation of spawning or 

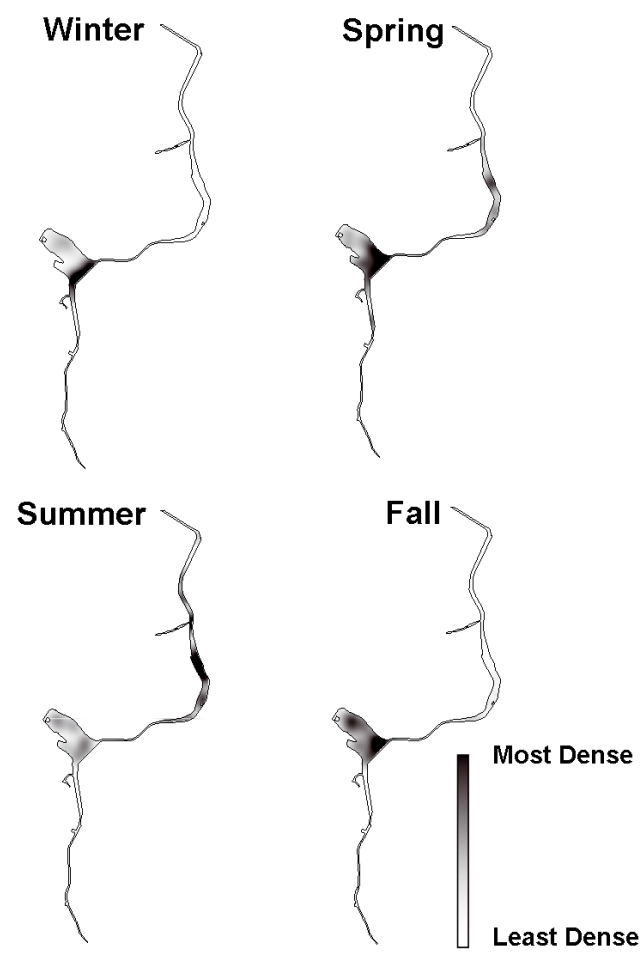

Fig. 4. The 95\% kernel home range estimates for the tagged muskellunge ( $n=8$; excludes fish that emigrated from the system or died) during the winter, spring, summer, and fall. White space indicates minimal or no position density, black indicates maximum position density, grey areas are intermediate.

egg deposition), the physical characteristics of the environment suggest suitable spawning habitat (Dombeck 1979).

In the Rideau Canal, the impact of the multiple lock stations and water level maintenance on urban muskellunge behaviour has yet to be determined. Muskellunge may benefit from decreased water levels over winter, as previous studies have suggested that self-sustaining muskellunge populations and high-hatching success are related to winter drawdown (Dombeck et al. 1984; Zorn et al. 1998). The drawdown period is believed to result in substrate aeration and organic material desiccation, forming a firmer substrate that may improve muskellunge spawning habitat (Dombeck 1986). However, fluctuations in water levels during spawning and egg production can be critical for muskellunge development, especially in regions where the water level is decreased (Zorn et al. 1998). Currently, the water level maintenance in the canal corresponds directly with the muskellunge spawning period. As this time period is critical for muskellunge survival in this unique system, it is necessary to examine the effects of the environmental changes to ensure that canal operations do not inversely influence the fitness of canal dwelling muskellunges.

The Rideau Canal represents a unique urban environment and it was initially theorized that the lock stations created a completely closed environment, in which muskellunge were permanent residents. The fact that during the study one fish left the reach suggests that the environment is not closed. If provided with the opportunity (i.e., the locks were opened at the right time) it is believed that fish would move from the canal to the Ottawa River (downstream) or Rideau River (upstream; Fig. 1). This is further supported by fish spending considerable time near the locks stations in the spring (transmitter code $=149.471)$ and summer (149.507). Rust et al. (2002) suggested that aquatic environments with self-sustaining muskellunge populations are surrounded by forest, whereas lakes that required stocking had less shoreline in a natural state and more shoreline development. The urban reaches of the Rideau Canal may not have the potential to sustain muskellunge populations due to an absence of appropriate spawning habitats or hydroperiods, perhaps requiring fish to move between the urban and non-urban stretches of the canal. Although we observed little emigration, there may be both emigration and immigration of younger life stages. A telemetry study focused on multiple adjacent reaches and life stages would be useful in clarifying the connectivity of the different reaches of the Rideau Canal.

Seasonal minimum displacement was not correlated with the size (i.e., length) of urban muskellunge (repeated-measures ANOVA; $F_{(1,6)}=10.727, p=0.230$ ). This is in contrast to previous studies on northern pike where size-dependent movements have been observed (Jepsen et al. 2001; Kobler et al. 2008 b). It has been proposed that reduced predation risk as well as an increased food demand is an incentive for larger fish to increase foraging activity, resulting in greater movement rates (Kobler et al. 2008b). As apex predators in the Rideau Canal, all muskellunge likely experience minimal predation risk and a similar food demand. If intraspecific competition is not a significant factor in the environment, it is possible that only minor movement differences may exist among individuals. Because our study only tracked 10 fish that were within a narrow size range, there may not have been enough variation to assess size-dependent habitat use.

In general, our study indicates that seasonality has a significant impact on home range and general movement patterns of adult muskellunge in the urban stretch of the Rideau Canal. In particular, transition periods in the spring and fall, and the warmer summer months showed greater home ranges and increased movement as compared to the winter months. Knowledge of the spatial ecology of muskellunge in this unique urban system will generate awareness in the ecology of urban aquatic systems and provide managers with insight into how canal operations influence muskellunge movement and habitat use. Specifically, the identification of potential spawning and over-wintering habitats will help managers to reduce winter mortality, while promoting the reproduction of muskellunge populations in this unique environment.

Acknowledgements. The authors would like to thank the Ottawa Chapter of Muskies Canada for the funding and field assistance provided during this study. We also thank current and former members of the Cooke Lab for their assistance in the field, particularly Michelle Roberge, Andrew Gingerich, Karen Murchie, Marie-Ange Gravel, Amos Mapleston, Lisa Thompson, Mike Donaldson, Kyle Hanson, Tara Redpath, and Connie O'Connor.

\section{References}

Anderson W.G., McKinley R.S., Colavecchia M., 1997, The use of clove oil as an anesthetic for rainbow trout and its effects on 
swimming performance. N. Am. J. Fish. Manage. 17, 301-307.

Bunt C.M., Cooke S.J., Katopodis C., McKinley R.S., 1999, Movement and summer habitat of brown trout (Salmo trutta) below a pulsed discharge hydroelectric generating system. Regul. R. Res. Manage. 15, 395-403.

Casselman J.M., 1978, Effects of environmental factors on growth, survival, activity, and exploitation of northern pike. Am. Fish. Soc. Spec. Pub. 11, 114-128.

Casselman J.M., 2007, Determining minimum ultimate size, setting size limits, and developing trophy standards and indices of comparable size for maintaining quality muskellunge (Esox masquinongy) populations and sports fisheries. Environ. Biol. Fish. 79, 137-154.

Casselman J.M., Robinson C.J., Crossman E.J., 1999, Growth and ultimate length of muskellunge from Ontario water bodies. N. Am. J. Fish. Manage. 19, 271-290.

Cooke S.J., Graeb B.D.S., Suski C.D., Ostrand K.G., 2003, Effects of suture material on incision healing, growth and survival of juvenile largemouth bass implanted with miniature radio transmitters: case study of a novice and experienced fish surgeon. J. Fish Biol. $62,1366-1380$.

Crossman E.J., 1956, Growth, mortality, and movements of a sanctuary population of maskionage. J. Fish. Res. Board Can. 13: 599612.

Coad B.W., 2001, Keys to the fishes of the National Capital Region. Trail and Landscape 35, 133-166.

Curry R.A., Doherty C.A., Jardine T.D., Currie S.L., 2007, Using movements and diet analyses to assess effects of introduced muskellunge (Esox masquinongy) on Atlantic salmon (Salmo salar) in the Saint John River, New Brunswick. Environ. Biol. Fish. 79, 49-60.

Diana J.S., Mackay W.C., Ehrman M., 1977, Movements and habitat preference of northern pike (Esox lucius) in Lac Ste. Anne, Alberta. Trans. Am. Fish. Soc. 106, 561-565.

Dombeck M.P., 1979, Movement and behavior of the muskellunge determined by radio-telemetry. Wisconsin Depart. Nat. Res. Tech. Bull. 113.

Dombeck M.P., Menzel B.W., Hinz P.N., 1984, Muskellunge spawning habitat and reproductive success. Trans. Am. Fish. Soc. 113, 205-216.

Dombeck M.P., 1986, Muskellunge habitat with guidelines for habitat management. Am. Fish. Soc. Spec. Publ. 11, 208-215.

Hanson D.A., Margenau T.L., 1992, Movement, habitat selection, behavior, and survival of stocked muskellunge. N. Am. J. Fish. Manage. 12, 474-483.

Heney M., 2009, Environmental consequences of fall drawdown in the Hog's Back to Hartwell's lock reach of Rideau Canal, Ottawa. BSc Honours Thesis. Carleton University, Ottawa, Ontario.

Hooge P.N., Eichenlaub W., Solomon E., 1999, The animal movement program. Alaska Biological Science Center, US Geological Survey, Anchorage, Alaska.

Jepsen N., Beck S., Skov C., Koed A., 2001, Behavior of pike (Esox lucius L.) $<50 \mathrm{~cm}$ in a turbid reservoir and in a clearwater lake. Ecol. Freshw. Fish. 10, 26-34.

Knight C.M., Gozlan R.E., Lucas M.C., 2008, Can seasonal home range size in pike Esox lucius predict excursion distance? J. Fish Biol. 73, 1058-1064.

Kobler A., Klefoth T., Arlinghaus R., 2008a, Site fidelity and seasonal changes in activity centre size of female pike Esox lucius in a small lake. J. Fish Biol. 73, 584-596.
Kobler A., Klefoth T., Wolter C., Fredrich F., Arlinghaus R., 2008b, Contrasting pike (Esox lucius L.) movement and habitat choice between summer and winter in a small lake. Hydrobiologia 601, $17-27$.

Magnuson J.J., Crowder L.B., Medvick P.A., 1979, Temperature as an ecological resources. Am. Zool. 19, 331-343.

Miller M.L., Menzel B.W., 1986a, Movement, activity, and habitat use patterns of muskellunge in West Okoboji Lake, Iowa. Am. Fish. Soc. Spec. Publ. 15, 51-61.

Miller M.L., Menzel B.W., 1986b, Movements, homing, and home range of muskellunge, Esox masquinongy, in West Okoboji Lake, Iowa. Environ. Biol. Fish. 16, 243-255.

Minor J.D., Crossman E.J., 1978, Home range and seasonal movements of muskellunge as determined by radiotelemetry. Am. Fish. Soc. Spec. Publ. 11, 146-153.

Murry B.A., Farrell J.M., 2007, Quantification of native muskellunge nursery habitat: influence of body size, fish community composition, and vegetation structure. Environ. Biol. Fish. 79, 37-47.

Parks Canada, 2005, Rideau Canal National Historic Site of Canada Management Plan. Ottawa, Canada, http://www.pc.gc.ca/docs/r/ on/rideau/pd-mp/page_04.aspx.

Phelps A., Renaud C.B., Chapleau F., 1999, Over one hundred years of change within the fish community of the Rideau River/Canal System, Ontario Canada. $38^{\text {th }}$ Annual Meeting of the Canadian Society of Zoologists, University of Ottawa, Ottawa, May 5-8 (abstract).

Rogers K.B., White G.C., 2007, Analysis of movement and habitat use from telemetry data. In: Brown M.L, Guy C.S. (Eds.) Analysis and Interpretation of Freshwater Fisheries Data, Bethesda Maryland, American Fisheries Society, pp. 625-676.

Row J.R., Blouin-Demers G., 2006, Kernels are not accurate estimators of home-range size for herpetofauna. Copeia 4, 797-802.

Rust A.J., Diana J.S., Margenau T.L., Edwards C.J., 2002, Lake characteristics influencing spawning success of muskellunge in northern Wisconsin lakes. N. Am. J. Fish. Manage. 22, 834-841.

Scott W.B., Crossman E.J., 1973, Freshwater fishes of Canada. Bull. Fish. Res. Board Can. $\mathrm{N}^{\circ} 184$.

Wachelka H.M., Lascelles M., Loewen M., 2000, Scoping report on fish and terrestrial habitat and water quality along the Rideau River. 56pp. (www.restoretherideau.org/resources/library. html, downloaded 16 July 2002).

Wagner C.P., Wahl D.H., 2007, Evaluation of temperature-selection differences among juvenile muskellunge originating from different latitudes. Environ. Biol. Fish. 79, 85-98.

Walker R.P., O’Toole A., Whynot Z., Hanson K.C., Cooke S.J., Evaluation of the aquatic habitat and fish assemblage in an urban reach of the historic Rideau Canal, Ottawa, Canada: implications for management in an engineered system. Urban Ecosyst.

Weeks J.G., Hansen M.J. 2009, Walleye and muskellunge movement in the Manitowish chain of lakes, Vilas County, Wisconsin N. Am. J. Fish. Manage. 29, 791-804.

Worton B.J., 1989, Kernel methods for estimating the utilization distribution in home-range studies. Ecology 70, 164-168.

Younk J.A., Cook M.F., Goeman T.J., Spencer P.D., 1996, Seasonal habitat use and movements of muskellunge in the Mississippi River. Minnesota Department of Natural Resources Investigational Report 449, 1-20.

Zorn S.A., Margenau T.L., Diana J.S., Edwards C.J., 1998, The influence of spawning habitat on natural reproduction of muskellunge in Wisconsin. Trans. Am. Fish. Soc. 127, 995-1005. 